\title{
Perils of public sector enterprises in India: is privatization of central public sector enterprises a sustainable strategy?
}

Abhijit Phukon and Divya Verma Gakhar

University School of Management Studies, Guru Gobind Singh Indraprastha University, New Delhi, India

\begin{abstract}
Purpose - This paper aims to attempt to empirically investigate the impact of privatization on the performance of central public sector enterprises in India. Further attempt is made to explore whether privatization is a necessary or sufficient condition for improvement of performance of central public sector enterprises.
\end{abstract}

Design/methodology/approach - The scope of the study is limited to financial and operating performance analysis of 206 central public sector enterprises in India. Multiple regression analysis has been used to determine the magnitude and direction of relationship between dependent and independent variables and identify variables other than privatization which affects performance.

Findings - The study found that financial and operational performance of firms has improved significantly due to privatization. Further, firm-specific factors and other parallel reforms adopted by enterprises have significantly influenced their performance. The established regression model is highly significant with F-ratio of 31.825 at $99 \%$ significance level. The degree of explanation of the model is robust with adjusted $R^{2}$ at 0.956 implying that only $4.40 \%$ of explanation in the dependent variable cannot be explained by designated independent/explanatory variables.

Originality/value - The study would be useful to public policymakers to reach to a policy view on whether further disinvestment/privatization of central public sector enterprises need to be continued, and if so, then to what extent and direction.

Keywords Performance, Disinvestment, Privatization, Central public sector enterprises,

Sustainable strategy

Paper type Research paper

\section{Introduction}

The genesis of public sector dates back to the origin of the First and the Second World Wars. Public-sector-driven economic activities came into existence after the First World War, especially to re-build the war devastated economies, to accelerate the pace of their development and to save their economies from the ravages of great depression. Further, post the Second World War, large number of countries in Asia, Africa and North America were

(C) Abhijit Phukon and Divya Verma Gakhar. Published in PSU Research Review. Published by Emerald Publishing Limited. This article is published under the Creative Commons Attribution (CC BY 4.0) licence. Anyone may reproduce, distribute, translate and create derivative works of this article (for both commercial and non-commercial purposes), subject to full attribution to the original publication and authors. The full terms of this licence maybe seen at http://creativecommons.org/ licences/by/4.0/legalcode

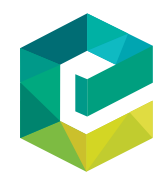


PRR

6,1

60

freed from European colonialism, and these countries were left with no options than public sector to play a greater role in the management and governance of the economy. In India also, public sector enterprises (PSEs) in the post-independence period played a major role in building economic, social and cultural foundations of the country. PSEs were corroborated as the "Engine of Growth", "Vehicle of Sustained Development", "Temples of Modern Industry" or "Commanding Heights of the Economy". It has, thus, been proved beyond doubt that both developed and developing countries have used PSEs as a vehicle for their sustained development.

With the passage of time and increased income and standard of living, while the aspirations of citizens have soared and multiplied, the capacity of PSEs has become limited to meet their aspirations. This led to service delivery gap or access-satisfaction gap, and so there was a felt need for institutional reforms to enhance the capacity of the public sector institutions to ensure effective delivery of core services. Resultantly, the traditional public service delivery mechanism has been shifted to "new public management" and "new public governance". Earlier studies established that development of new public management is a response to the perceived failings of public administration (Osborne et al., 2014). Successive economic crisis followed by increase in public debt led to new institutional arrangements for the delivery of public services. Notably, the Statement of Industrial Policy 1991 clearly stipulated that to raise resources and encourage wider public participation, a part of the government's shareholding in the public sector would be offered to mutual funds, financial institutions, general public and workers. The Indian privatization drive had boosted up and came out of the political camouflage when Government of India in the Parliament budget session (2002) stated that:

It is evident that disinvestment in public sector enterprises is no longer a matter of choice but an imperative [...] The prolonged fiscal haemorrhage from the majority of these enterprises cannot be sustained any longer, [...][...]

Resultantly, a large number of Central Public Sector Enterprises (CPSEs) have been put through disinvestment, while some others have been privatized over the years. Of the 234 operational CPSEs, 81 CPSEs (including 20 Hotels of Hotel Corporation of India) have been divested for 195 times over the period 1991-1992 to 2015-2016 (some CPSEs have been divested for multiple times). As few decades have passed and we have adequate learning experiences, it would be in the larger public interest to review how disinvestment/ privatization through divestiture of equity and/or change in ownership affect the financial and operational performance of CPSEs and whether it is a sustainable strategy. Before we move ahead further, it is essential to mention here that disinvestment in the Indian context is used especially where the equity holding of the government in a PSE is off loaded, but government still holds more than $50 \%$ equity with full management control of the PSE. On the other hand, privatization is used only when the equity holding of the government in a PSE is off loaded and the government holds less than $50 \%$ equity with transfer of management control to the private. As disinvestment is the initial stage of privatization, for the purpose of ease of reference, the word "privatization" has been interchangeably used with the word "disinvestment" throughout the study.

\section{Objectives of the study}

Privatization has become a global phenomenon and a strategic policy tool to motivate the performance of public sector through allocation of resources by exercising market forces. Kousadikar and Singh (2013) observed that privatization of state-owned enterprises (SOEs) have been developed as a critical tool for economic policies pertaining to progress and 
development of developing countries. Over time, policymakers have shed their inhibitions about privatization and have formulated liberal reforms to enhance efficiency and profit of the SOEs. Chattopadhyay (2011) made an attempt to understand the reasons behind the failure to uphold proper governance of CPSEs in India and found that large part of the business entities, often criticized because of inefficiency and improper governance, are actually due to conflicting objectives, excessive government interference, lack of managerial and commercial autonomy and controlled pricing mechanism. Farris et al. (2010) noted that sustainable business practice in commercial markets has traditionally been equated with a enterprises in India healthy "bottom line" profitability that provides a return for shareholders and/or owners . Whereas the traditional business model in the private sector is based upon the single bottom line of organizational profitability as a measure of sustainability, the public service business model is based upon public value rather than an organizational single bottom line of profitability. In view of this, it is proposed to:

- analyse the impact of disinvestment on the financial and operating performance of the central public sector enterprises in India;

- identify the key determinants other than disinvestment which affect their performances; and

- investigate whether disinvestment is a necessary or sufficient condition for improvement of performance of central public sector enterprises.

\section{Review of past studies}

Nosratabadi et al. (2019) found that innovative business model brings a competitive advantage to improve the sustainability performance of an organization. It describes the rationale of how an organization creates, delivers and captures value in economic, social, cultural or other contexts, in a sustainable way. The process of sustainable business model construction forms an innovative part of a business strategy. They have found that popularity and success rate of sustainable business models in all application domains have been increased along with the increasing use of advanced technologies. Many research studies (Hossain et al., 2019; Yadav et al., 2019; Hossain et al., 2020) have found that innovative entrepreneurial spirit, uses of state-of-the-art technology such as Internet of Things (IoT), innovative customer-centric approach such as social networking and online platforms such as e-commerce are fundamental to sustain in this open competitive global business environment. Omran (2004) noted that privatization has been a major political and economic phenomenon over the past few decades, and researchers continue to target it for both theoretical and empirical work. Given that most socialist and communist economies from every region in the world have recently started implementing economic reform programs, the reduction in size of the public sector through privatization has therefore become an important part of such programs. A careful analysis of the history of literature on impact of disinvestment/privatization reveals that there are three school of thoughts:

(1) Those who believes that privatization improves efficiency and thereby performance of firms. Megginson et al. (1994), Djankov and Murrell (2002), McKenzie and Mookherjee (2002), Wolf and Pollitt (2008), Pratap (2011), Kumar (2014) and Ojonugwa and lrunmoluo (2015) have found a significant improvement in the post-privatization performance of firms. They claim that privatization leads to improvement in performance of firms as they do away with political interferences and divert their attention towards economic objective of maximizing returns over their investment. For example, Gupta (2005) noted that selling minority equity stakes without the transfer of 
PRR

6,1

62

management control leads to a significant increase in the level and growth rates of profitability, labour productivity and investment spending. Investment spending on research and development and expenditures on fixed capital also rise significantly following an increase in private ownership share. Privatizing SOEs could attract foreign investment, increase domestic investment, develop financial markets and release scarce public funds for other uses such as investment in infrastructure. Similarly, McKenzie and Mookherjee (2002) found that only signs of an adverse distributive impact on the bottom half of the distribution appear with respect to a small proportion of workers that were displaced from their jobs in state-owned enterprises, with many of them probably getting rehired subsequently elsewhere in the economy. This suggests that future privatization programmes can be designed in particular ways to minimize the adverse nature of their distributive impact. The fiscal impact of reforms seems generally to have had favourable distributive consequences by aiding macroeconomic stabilization and allowing a shift in public spending away from expensive debt service obligations and funding operating losses in SOES towards increased social spending. Verma Gakhar and Phukon (2018) concluded that around $61 \%$ of the studies reveal positive effects of privatization on performance in terms of operating efficiency, cost and price efficiency, easy access to market based finance facility, transparency and good governance, productivity and profitability. They further established ample research evidences which support the proposition that privately owned firms are more efficient and profitable than its counterpart SOEs.

(2) Those who have found a neutral effect of privatization and believe that privatization may or may not improve firm performance are Megginson and Netter (2001), Jain (2011), Rastogi and Shukla (2013), Potter (2015), Khurud and Abhang (2016). They are of the view that though privatization may provide room to improve efficiency and hassle-free working environment, it may convert into private monopoly which is more dangerous than public monopoly. For instance, Parker (2004) concluded that effective privatization requires an ecosystem of competition and regulation as evident from UK's experience to ensure that state monopolies does not turn into private monopolies which is more painful.

(3) Those who firmly believes that privatization does not have any significant impact on firm's performance includes Nagaraj (1997), Bevan et al. (1999), Gupta (2005), Sathye (2005), Nagaraj (2006), Bortolotti and Milella (2006), Paterson et al. (2006), Etrogiovanna (2010), Mohamed (2010), Ntiri (2010), Kousadikar and Singh (2013), Ritu (2015) and Poczter (2016). They argued that the real problem of public sector is not the lack of efficiency but one of pricing and collection of user charges, unless these problems are squarely addressed, public sector performance are unlikely shape up. There is no doubt that the gains of privatization come with a certain cost such as increase in price level, artificial shortage of resources, formation of likeminded cartel, job insecurity, social security and safety net, corporate social responsibility and protection of stakeholder's rights. The social welfare element is affected because of their profit maximizing behaviour and looking for only affordable customers rather than serving the society at large.

\section{Theoretical model building}

While fiscal indiscipline, unsustainable budget deficits, consistent funding obligations and inefficient operations are some common factors precipitating privatization of PSEs in many countries, including several countries in Asia and Latin America, justification for 
privatization is also driven by ideology and efficiency grounds as well. From a careful analysis of disinvestment policy of India evolved in the past three decades, it is found that disinvestment of public sector enterprises were driven by a mixture of both compelling forces such as meeting deficit financing, emergence of many public enterprises as sick units and forced them to close their business operation, as well as competing forces such as efficiency enhancement, financial autonomy and transparency, depending on the existing social, political and economic situations of the country. The 195 disinvestment incidences through which 81 CPSEs were divested and/or privatized as on 31.03.2016 are based on enterprises in India these principles. It is also noted that the government introduced massive structural reforms of PSEs in the form of greater autonomy, more financial delegation, board-driven governance mechanisms, corporate governance codes, transparency and accountability, listing in stock exchanges, introducing Maharatna/Navratna/Miniratna scheme based on their financial and managerial autonomy. Not only has this resulted improve performance of CPSEs but also some CPSEs have emerged as the top 500 Fortunes companies in the world. Therefore, disinvestment/privatization coupled with other reform measures affect the performance of these enterprises. From the literature review also, we have found that performance is a relative concept and is being affected by a range of factors other than disinvestment/privatization. These could be firm-specific factors (such as age, size, liquidity, solvency, profitability, efficiency, market performance of the firms) and parallel reform measures (such as financial and managerial autonomy extended to the firms, execution of performance contract, listing in the stock exchanges, implementation of corporate governance principles). Authors who have used these proxies as independent/control/ dummy variables are Size of the Firm (Ozgulbas et al., 2006; Astami et al., 2010); Age of the Firm (Rajeev and Vani, 2004); Industry sector operated (Halkos and Salamouris, 2003; Astami et al., 2010); Degree of autonomy (Gupta et al., 2011; Mathur and Mathur, 2010; Gunasekar and Sarkar, 2015); Performance contract/MoU (Gupta et al., 2011; Simpson, 2013; Gunasekar and Sarkar, 2015); Listing in Stock Exchanges (Megginson and Netter, 2001; Rao and Guha, 2006; Banaluddin, 2007; Wolf and Pollitt, 2008); Corporate governance (World Bank, 2010; Chattopadhyay, 2011; Semmar, 2012; Som, 2013; D'silva and Joseph, 2013); Asset-in-place (Astami and Tower, 2006; Astami et al., 2010); Financial leverage (Astami et al., 2010). The analysis leads to a theoretical model on how disinvestment/privatization of CPSE along with firm's specific factors and parallel reform measures affect its performance (Figure 1).

Research Model

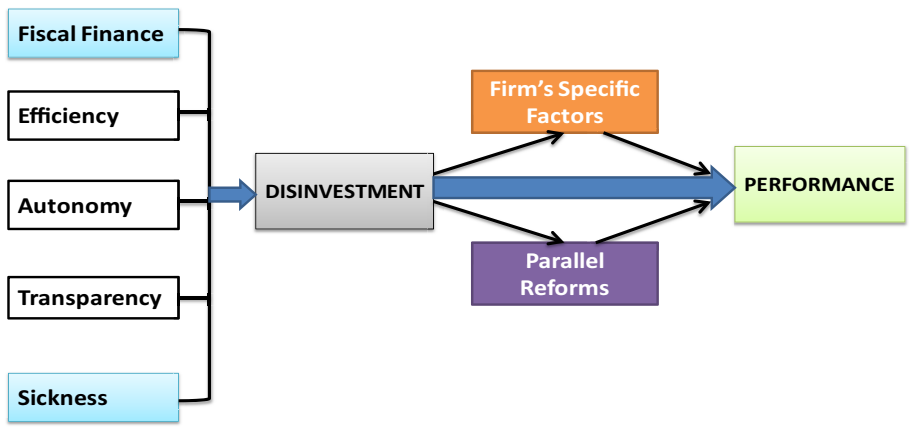

Figure 1. Conceptual model 
PRR

6,1

\section{Methodology of the study}

In the study, multiple regression analysis has been used especially to identify the variables other than disinvestment/privatization which affects the performance of CPSEs, the magnitude and direction of relationship between dependent/criterion variable (i.e. performance) and independent/predictor variables (i.e. privatization and other independent variables). Studies which applied such techniques are Sathye (2005), Banaluddin (2007), Kumar (2014), Kim and Chung (2000), Astami et al. (2010), Liu et al. (2015), Shi and Sun (2016) and Rajeev and Vani (2004). The study is based on the following regression model:

$$
\begin{aligned}
& \text { Performance }=\mathrm{f}[(\text { Disinvestment })+(\text { Firm Specific Factors })+(\text { Parallel Reforms }) \\
& +\ldots \ldots \ldots \ldots \ldots+\notin] \\
& \mathrm{Y}=\mathrm{a}+\sum_{\mathrm{i}=1}^{\mathrm{n}} \mathrm{b}_{\mathrm{i}} \mathrm{X}_{\mathrm{i}}+€_{\mathrm{i}} \\
& \mathrm{Y}=\mathrm{a}+\mathrm{b} 1 \mathrm{X} 1+\mathrm{b} 2 \mathrm{X} 2+\mathrm{b} 3 \mathrm{X} 3+\mathrm{b} 4 \mathrm{X} 4+\ldots \ldots \ldots \ldots+\mathrm{bnXn}+\notin \mathrm{n} \\
& \mathrm{Y}=\text { Dependent variable performancea }=\text { Intercept } / \text { Constant } \\
& \mathrm{b}_{1}, \mathrm{~b}_{2}, \mathrm{~b}_{3}, \mathrm{~b}_{4} \ldots \ldots \ldots \mathrm{b}_{\mathrm{n}}=\text { Regression slopes } / \text { Regression coefficients } \\
& \mathrm{X}_{1}, X_{2}, \mathrm{X}_{3}, \mathrm{X}_{4} \ldots \ldots \mathrm{X}_{\mathrm{n}}=\text { Independent variables which affect the dependent variable } \\
& \text { performance, and } \\
& €_{n} \quad=\text { Residuals or Error term which have a normal distribution } \\
& \text { with mean } 0 \text { and constant variance } \sigma^{2} \text {. }
\end{aligned}
$$

The purpose of using multiple regression analysis is to determine the explanatory variables that have a significant effect in explaining the dependent variable "performance". In the above equation, while performance is measured in terms of RoNW, the explanatory or independent variables include mainly three types of variables, i.e. disinvestment/ privatization, firm-specific factors and other reform initiatives, that are taking place parallelly. Disinvestment is measured in terms of disinvestment efficiency. Firm-specific factors are measured in terms of age, size, liquidity, solvency, profitability, efficiency, market performance of firms, etc., and parallel reforms are measured in terms of dummies such as financial and managerial autonomy extended to the firms, execution of performance contract, listing in the stock exchanges and implementation of corporate governance principles. The sample design follows a multi-stage sampling method. In India, as on March 31, 2016, there were 290 non-financial CPSEs operated into five different broad sectors such as agriculture, mining, manufacturing, electricity and service sector. Of this, 234 CPSEs were operational and balance 56 were under construction. Of the 234 operational CPSEs, some CPSEs were not functioning on commercial basis, and for some CPSEs, data was not available, and these CPSEs have been excluded from the list of sample size. Hence, the study is based on a target sample size of 206 CPSEs.

\section{Hypothesis}

H1. Disinvestment efficiency does not significantly influence the performance of firm. 
H2. The presence of firm-specific factors and reforms process does not have significant influence on the performance of firm.

\section{Statistical results}

In the initial model, we have considered as high as 30 explanatory variables such as net worth (NW), total assets (TA), capital employed (CE), gross working capital (GWC), net profit margin (NPM), dividend rate (DR), net sales (NS), overhead cost (OC), sales efficiency (SE), net income efficiency (NIE), raw-material turnover ratio (RTR), debt equity ratio (DER), interest coverage ratio (ICR), cash ratio (CR), market coverage (MC), enterprise value (EV), earnings per share (EPS), profit or loss (POL), industry sector (IS), ownership structure (OS), percent stake divested (PSD), disinvestment amount realized (DAR), disinvestment efficiency (DE), number of years of disinvestment (NYD), expenditure on R\&D (ERD), autonomy (ATMY), performance contract (PC), listing in the stock exchanges (LSE), PE ratio (PER) and corporate governance (CG). However, some of these variables are highly correlated, and these highly correlated variables have been removed from the model by applying backward elimination method to avoid any spurious regression results. Thus, in the final regression model (Table A1), we have left with 17 explanatory variables, i.e. CE, RTR, ICR, MC, CR, DR, EPS, GWC, ERD, SE, NIE, DE, POL, IS, PC, LSE and CG. All the 17 variables that have been entered into the final model follow a normal distribution as tested by Kolmogorov-Smirnov test. Auto-correlation is checked through correlation coefficient matrix. To check the problem of multi-co-linearity, we have calculated the Eigen value of the 17 variables and none of their value is near zero. Multi-co-linearity is therefore not a major problem. The independence of error terms or autocorrelation of residuals is tested with the help of Durbin-Watson test. As the calculated value of Durbin-Watson (1.633) is less than critical benchmark value (3.00), there appears to be no autocorrelation of residuals in the established regression model. The normality of the residuals is also tested by applying Kolmogorov-Smirnov test, which shows that residual follow a normal distribution and therefore, the problem of heteroscedasticity does not exist.

The evaluated regression model is highly significant as the F-ratio is 31.825 at $0.000 \%$ level of significance. The degree of explanation of the model is robust with adjusted $R^{2}$ at 0.956 implying that only $4.40 \%$ of the explanation in the dependent variable (i.e. performance in terms of RoNW) cannot be explained by the designated independent/ explanatory variables. Alternatively, only $4.40 \%$ of the explanation in the dependent variable by the 17 independent variables may be due to chance or error. The model further says that any change in the dependent variable due to a change in any of the 17 independent variables is $95.60 \%$ accurate. It is evident that while the effect of disinvestment is significant, the presence of firm specific factors and parallel reforms has also affected the performance of CPSEs. The alternate $H 1$ and $H 2$ are therefore rejected.

\section{Analysis and discussion}

The study has established that the financial and operational performance of CPSEs have improved significantly after disinvestment/privatization. This means that disinvestment/ privatization has positive impact on the performance of CPSEs in India. This finding is supported by many past studies. For example, D'Souza and Megginson (1999) found that privatized firms that work in competitive industries are likely to yield solid and rapid economic benefits as long as there are no economy-wide distortions that hinder competition. Djankov and Murrell (2002) concluded that the aggregate effects of privatization are positive. However, varying consequences of privatization across transition economies could be due to their 
PRR

6,1

66

supportive institutions, such as courts for promoting the rule of law, generation of sound competition and corporate governance policies. Rajeev (2004) noted that government does not have the best managerial skills and if it waits till a factory becomes sick, there is no other alternative but to opt for closure whereby the workers suffer the most. Hence, restructuring and privatizing even the profit-making enterprises are essential subject to the condition that there is strong presence of private sector and well-functioning market system. Gupta (2005) expressed that competition plays an important role in the privatization process and improves performance of public sector enterprises. Sathye (2005) found that financial performance and efficiency of partially privatized banks were significantly higher than that of the fully public banks and partially privatized banks seem to be catching up fast with fully private banks. Kim and Chung (2000) found statistically significant positive relationship between privatization pressure and operating efficiency of state-owned enterprises (SOEs). This may be due to SOEs' managers and employees when face privatization pressure, are subjected to hard budget constraint. This implies that while finding ways to privatize SOEs, policymakers need to continually apply privatization pressures on SOE managers to impose hard budget constraints on SOEs. Similarly, Jain (2011) performance level has not only depended upon the extent of disinvestment but also on the managerial policies, philosophy and procedures of public enterprises. Singh (2015) found that disinvestment can lead to increase in efficiency through better utilization of resources but reckless privatization may not provide the ultimate solution over long time as efficiency may be achieved by changing the quality of management and not only by changing the ownership. Verma Gakhar and Phukon (2018) have documented that privatization is a necessary but not sufficient condition for improvement of firm's performance. The State must commit to take forward parallel reforms along with privatization to actualize the performance of SOEs. It can, therefore, be concluded that disinvestment/privatization can be seen as a means of development but not an end in itself.

The study has also found that firm specific factors and other parallel reforms adopted by the firms are significantly influencing their performance. This means that disinvestment/ privatization is not the only factor which affects the performance of CPSEs. Performance of CPSEs is affected by variety of factors including age and size of the CPSE, liquidity, solvency, profitability, efficiency, market performance, financial and managerial autonomy, execution of performance contract, listing in the stock exchanges, implementation of corporate governance principles, etc. This has been supported by many past studies. For example, Estrin et al. (2009) in a study of 34 privatization case studies found that privatization, especially when accompanied by complementary reforms, have a positive effect on the level of aggregate output. Privatization per se does not guarantee improved performance, at least not in the short to medium run. The type of private ownership, corporate governance, access to know-how and markets, legal and institutional systems matter for firms restructuring and performance. Parker (2004) looked at the relative roles of competition, regulation and ownership changes in determining performance improvement of the newly privatized SOEs. The study concluded that effective privatization requires an ecosystem of competition and regulation as evident by UK's experience to ensure that state monopolies does not turn into private monopolies which is more painful. Kim and Kim (2007) concluded that it is necessary to recognize privatization as a long-term and complex process of change, including changes in attitudes, values, perceptions and mentality. Bardhan and Roaner (1992) found that full-scale private ownership is not necessary for the successful operation of competition and markets. Even in management literature, one does not find any analytical support for the alleged superior efficiency of private ownership. Nagaraj (2006) stated that the real problem is not the lack of efficiency in production, but one of pricing and collection of user charges, unless these problems are squarely addressed, 
public sector finances are unlikely shape up. Koner and Sarkhel (2014) contested that through disinvestment and privatization, the government is substituting private monopoly in place of public monopoly. They suggested that restructuring of PSUs is essential before they are being divested so as to enhance the value of shares and increase sale proceeds. Kaur (2003) concluded that factors which enhance the level of competition in an economy may be more important determinants of efficiency than a change of ownership per se. The emphasis therefore must be towards creating a more competitive environment than merely transferring the ownership of assets from the public to the private sector. Bortolotti and enterprises in India Milella (2006) noted that ownership and control in privatized companies in Western Europe has been partial and incomplete. In most cases, privatization did not entail a dramatic change in governance structures as private ownership and public control actually seem to coexist. European governments firmly controlled (by voting rights and golden shares), a large part of the privatized companies, especially in strategic sectors. Understanding whether the coexistence of private ownership and public control is a European transient anomaly or a functional pattern of governance is important for policy reasons and might be an exciting avenue for future research.

\section{Industry application/practical implication}

From the study, it appears that performance of firm is affected by a range of factors, starting from firm-specific factors such as nature and size of the firm to various reforms initiatives undertaken by them taking into account global business dynamics such as adoption of stateof-the-art technology ethical corporate governance, financial prudence, listing, delegation for faster decision-making, etc. Thus, only the transfer of ownership from public to private through disinvestment/privatization is not sufficient to improve the performance of firms. Firms that do not allow their technology, products and functioning to align with global standards and with evolving market may suffer in the years to come. They may slip into bleak financial and market conditions.

Though change in ownership from public to private affects economic efficiency of CPSEs, it is felt that transfer of ownership coupled with policies for increased competition and level playing field would affect their performance to a great extant. CPSEs may be restructured as per market conditions and then expose them to competition with counterpart private sector firms which will enhance their efficiencies, an alternative to privatization and ownership transfer. It is found that increase in competitive pressures during the early reforms era in India forced firms to adopt a variety of strategies including mergers/ acquisitions/amalgamation, more reliance on in-house research and development, building marketing and distribution related complementary assets as part of product differentiation strategy. It also raised the importance of sub-contracting and outsourcing of manufacturing activities and reduced the degrees of vertical integration. Resultantly, the export orientation increased significantly across CPSEs signalling their enhanced global competitiveness. The study would be useful to public policy makers to reach to a policy view on whether to simply transfer ownership or transfer ownership with increased competition or expose restructured public enterprises into competition for enhancing their efficiencies.

\section{Conclusion}

It is essential to analyse how political economy decisions of privatization affects efficiency, competition, growth and sustainability of PSEs. The study has established that financial and operational performance of CPSEs has improved significantly due to disinvestment/ privatization. The study has also found that firm specific factors and other parallel reforms adopted by the firms have significantly influenced their performance. The study, therefore, 
PRR

6,1

carries a clear message that though disinvestment positively affects performance of public sector enterprises, but it is not sufficient to improve their performance in the absence of strong firm specific fundamentals and other reforms measures taken by the public authority. Further, to ensure that disinvestment/privatization is sustainable, public authority must ensure that a robust regulatory and institutional framework for disinvestment is put in place, the enterprise to be divested/privatized is chosen carefully and put through a well-equipped privatization method at a time conducive to organizational, economic, financial, political and social forces. Further to make disinvestment/privatization a sustainable business model, it is essential that the premise of disinvestment/privatization is based on the principles of harnessing efficiency, competition, innovation, costeffectiveness, better price discovery, etc., and not meeting target of fiscal finance.

\section{References}

Astami, E.W. and Tower, G. (2006), "Accounting policy choice and firm characteristics in the Asia pacific region: an international empirical test of costly contracting theory", The International Journal of Accounting, Vol. 41 No. 1, pp. 377-394.

Astami, E.W., Tower, G., Rusmin, R. and Neilson, J. (2010), "The effect of privatisation on performance of state-owned-enterprises in Indonesia”, Asian Review of Accounting, Vol. 18 No. 1, pp. 5-19.

Banaluddin, I. (2007), "The operating and financial performance of newly privatized state owned enterprises in Malaysia”, Ph D Thesis, University of Malaysia, available at: https://core.ac.uk/ works $/ 16238411$

Bevan, A.A., Estrin, S. and Schaffer, M.E. (1999), "Determinants of enterprise performance during transition”, CERT Working Paper No. 99/03, Centre for Economic Reform and Transformation, Heriot Watt University, available at: www2.hw.ac.uk/sml/downloads/cert/wpa/1999/dp9903.pdf

Bortolotti, B. and Milella, V. (2006), "Privatization in Western Europe: Stylized facts, outcomes, and open issues”, FEEM Working Paper No. 124.06, available at: https://ssrn.com/abstract=936911 or doi: $10.2139 / \mathrm{ssrn} .936911$.

Chattopadhyay, C. (2011), "Corporate governance and public sector units in India: a review", International Conference on Humanities, Society and Culture; IPEDR, IACSIT Press, Singapore, Vol. 20.

D'Silva, B. and Joseph, A.B. (2013), "A study on the implications of corporate restructuring", International Journal of Management and IT, Vol. 2 No. 1, pp. 39-48.

D'Souza, J. and Megginson, W.L. (1999), "The financial and operating performance of privatized firms during the 1990s", The Journal of Finance, Vol. 54 No. 4, pp. 1-44.

Djankov, S. and Murrell, P. (2002), "Enterprise restructuring in transition: a quantitative survey", Journal of Economic Literature, Vol. 40 No. 3, pp. 739-792.

Etrogiovanna, R.G. (2010), "The benefits of privatization? The Mexican experience in the telecommunications industry", Paper presented at the Emerging Research on Political Economy and Public Policy Conference, London School of Economics and Political Science, available at: www.lse.ac.uk/europeanInstitute/events/2008-09/Gonzalez_Pietrogiovanna.pdf.

Farris, P.W., Bendle, N.T., Pfeifer, P.E. and Reibstein, D.J. (2010), Marketing Metrics: The Definitive Guide to Measuring Marketing Performance, 2nd ed., Wharton School Publishing (O2010, ISBN:01370582929780137058297.

Gunasekar, S. and Sarkar, J. (2015), "Does autonomy matter in state owned enterprises? Evidence from performance contracts in India”, Indira Gandhi Institute of Development Research (IGIDR), Working Paper, WP-2014-034. 
Gupta, N. (2005), "Partial privatization and firm performance", The Journal of Finance, Vol. 60 No. 2, pp. 987-1015.

Gupta, S., Jain, P.K., Yadav, S.S. and Gupta, V.K. (2011), "Financial performance of disinvested Central public sector enterprises in India: an empirical study on select dimensions", Journal of Applied Finance and Banking, Vol. 1 No. 4, pp. 57-106.

Halkos, G.E. and Salamouris, D.S. (2003), "State owned enterprises, privatization and the public interest: evidence of S.O.E. performance in the Greek manufacturing”, Archieves of Economic History, Vol. XV No. 1, pp. 97-110.Munich Personal RePEC Archive (MPRA) Paper No. 39604.

Hossain, S.F.A., Xi, Z., Nurunnabi, M. and Hussain, K. (2019), "Ubiquitous role of social networking in driving M-Commerce: evaluating the use of mobile phones for online shopping and payment in the context of trust", SAGE Open, Vol. 10 No. 3, pp. 1-11, doi: 10.1177/2158244020939536, available at: https://journals.sagepub.com/home/sgo

Hossain, S.F.A., Nurunnabi, M., Hussain, K. and Shan, X. (2020), "Smartphone-based m-shopping behavior and innovative entrepreneurial tendency among women in emerging Asia", International Journal of Gender and Entrepreneurship, Vol. 12 No. 2, pp. 173-189, doi: 10.1108/ IJGE-03-2019-0054.

Hossain, S.F.A., Shan, X., Musa, M. and Rahman, P. (2020), Social Media and Increased Venture Creation Tendency with Innovative Ideas: The Case of Female Students in Asia, IGI Global, DOI: 10.4018/978-1-7998-0357-7.ch011.

Hossain, S.F.A., Xi, Z., Nurunnabi, M. and Anwar, B. (2019), "Sustainable academic performance in higher education: a mixed method approach", Interactive Learning Environments, doi: 10.1080/ 10494820.2019.1680392.

Jain, N. (2011), "Application of disinvestment on PSEs", International Journal of Commerce and Business Management, Vol. 4No. 1, pp. 74-92.

Khurud, B.S. and Abhang, S.B. (2016), "Performance review of disinvestment policy of India: a study of post reform era", European Academic Research, Vol. III No. 10, pp. 10875-10888.

Kim, J. and Chung, H. (2000), "Empirical study on the performance of state-owned-enterprises and the privatizing pressure: the case of Korea", International Review of Public Administration, doi:10.1080/12294659.2000.10804957, available at: http://regulation.upf.edu/utrecht-08-papers/ jkim.pdf.

Kousadikar, A. and Singh, T.K. (2013), "Advantages and disadvantages of privatisation in India", International Journal of Advanced System and Social Engineering Research, Vol. 3 No. 1, pp. 18-22.

Kumar, P. (2014), "Impact of disinvestment on profitability of selected public sector units", International Journal of Reviews, Surveys and Research, Vol. 3 No. 2, pp. 28-42.

Liu, G.S., Beirne, J. and Sun, P. (2015), "The performance impact of firm ownership transformation in China: mixed ownership vs. Fully privatised ownership", Journal of Chinese Economic and Business Studies, Vol. 13 No. 3, pp. 197-216.

McKenzie, D. and Mookherjee, D. (2002), "Distributive impact of privatization in Latin America: an overview of evidence from four countries (Argentina, Bolivia, Mexico and Nicaragua)", research project commissioned by the Inter-American Development Bank, available at: www.bu.edu/ econ/files/2012/11/dp128.pdf.

Mathur, R. and Mathur, B.L. (2010), "Performance evaluation of Central public enterprises in global perspective- a case study of India", International Conference on Applied Economics-ICOAE, 2010.

Megginson, W.L. and Netter, J.M. (2001), "From state to market: a survey of empirical studies on privatization”, Journal of Economic Literature, Vol. 39 No. 2, pp. 321-389.

Megginson, W.L., Nash, R.C. and Randenborgh, M.V. (1994), "The financial and operating performance of newly privatized firms: an international empirical analysis", The Journal of Finance, Vol. 49 No. 2, pp. 403-452. 
PRR

6,1

Mohamed, A.R. (2010), "Privatization and foreign direct investment", Springer US, The Saudi Arabian Economy, pp. 323-349, ISBN: 978-1-4419-5987-4.

Nagaraj, R. (1997), "What has happened since 1991 - an assessment of economic reforms", Economic and Political Weekly, Vol. 32 No. 44/45, pp. 2869-2879.

Nagaraj, R. (2006), "Public sector performance since 1950- A fresh look", Economic and Political Weekly, Vol. 41 No. 25, pp. 2551-2557.

Nosratabadi, S., Mosavi, A., Shamshirband, S., Zavadskas, E.K., Rakotonirainy, A. and Chau, K.W. (2019), "Sustainable business models: a review", Sustainability Review, Vol. 11 No. 6, pp. 1663, doi: 10.3390/su11061663, available at: www.mdpi.com/journal/sustainability

Ntiri, C.A. (2010), "Can the performance of State-Owned enterprises improve when privatized? A case study of Ghanaian based firms", BIT School of Management, available at: www.diva-portal.org/ smash/get/diva2:831203/FULLTEXT01.pdf

Ojonugwa, U. and Lrunmoluo, J. (2015), "Does privatization increase firm performance in Nigeria? An empirical investigation”, MPRA Paper No. 69675, Eastern Mediterranean University, available at: https://mpra.ub.uni-muenchen.de/69675/

Omran, M. (2004), "The performance of state-owned enterprises and newly privatized firms: does privatization really matter?", World Development, Vol. 32 No. 6, pp. 1019-1041, doi: 10.1016/j. worlddev.2004.01.006.

Osborne, D., Huo, Y. and Smith, H.J. (2014), "Organizational respect dampens the impact of group-based relative deprivation on willingness to protest pay cuts", British Journal of Social Psychology, Vol. 54 No. 1.

Ozgulbas, N., Koyuncugil, A.S. and Yilmaz, F. (2006), "Identifying the effect of firm size on financial performance of SMEs", The Business Review, Vol. 6 No. 1, pp. 162-167.

Parker, D. (2004), "The UK's privatisation experiment: the passage of time permits a sober assessment”, CESifo Working Paper Series 1126, CESifo Group Munich, available at: https:// papers.ssrn.com/sol3/papers.cfm?abstract_id=514224

Paterson, A., James, B. and Karimi, A. (2006), "Putting the cart before the horse? Privatisation and economic reform in Afghanistan", Briefing Paper Series, Afghanistan research and evaluation unit, available at: https://areu.org.af/wp-content/uploads/2016/01/632E-Putting-the-Cart-Beforethe-Horse-BP-web.pdf

Poczter, S. (2016), "The long-term effects of bank recapitalization: evidence from Indonesia”, Journal of Financial Intermediation, Vol. 25 No. C, pp. 131-153.

Potter, A. (2015), "Privatization in Ghana successes during economic collapse and authoritarianism", Discussion Paper of CUTS International, available at: www.cuts-ccier.org/pdf/Privatisation_ in_Ghana-Alan_Potter.pdf

Pratap, K.V. (2011), "Does privatization lead to benign outcomes? A case study of India", Sanford Journal of Public Policy, Vol. 2 No. 1, pp. 225-237.

Rajeev, M. (2004), "Reforms in state public enterprises in Karnataka: a review”, institute for social and economic change", Working Paper 2004-05.

Rajeev, M. and Vani, B.P. (2004), "Performance of public enterprises in Karnataka a panel data analysis", institute for social and economic change", Working Paper No. 152.

Rao, C. and Guha, K.S. (2006), "Ownership pattern of the Indian corporate sector: Implications for corporate governance”, Working Paper No. 2006/09, New Delhi Institute for Studies in Industrial Development.

Rastogi, M.K. and Shukla, S.K. (2013), "Challenges and impact of disinvestment on Indian economy", International Journal of Management and Business Studies, Vol. 3No. 4, pp. 44-53.

Kumar, K. and Kumar, C. (2015), "Disinvestment policy in India: progress and challenges", International Research Journal of Management and Commerce, Vol. 2 No. 2, pp. 1-12. 
Sathye, M. (2005), "Privatization, performance, and efficiency: a study of Indian banks", Vikalpa: The Journal for Decision Makers, Vol. 30 No. 1, pp. 7-16.

Semmar, A. (2012), "Corporate governance of state owned enterprises in Morocco, evolution and perspectives", OECD Conference on Towards New Arrangements for State Ownership in the Middle East and North A frica, OECD.

Shi, W. and Sun, J. (2016), "The impact of privatization on efficiency and profitability: evidence from Chinese listed firms, 2001-2010", Economics of Transition, Vol. 24 No. 3, pp. 393-420.

Simpson, S.N.Y. (2013), "Performance contract and performance evaluation of state-owned enterprises: insights from the goal setting theory", Journal of Public Administration and Governance, Vol. 3 No. 2, pp. 10-21.

Singh, G. (2015), "Disinvestment and performance of profit and loss making Central public sector enterprises of India", Indian Journal of Research, Vol. 4 No. 4, ISSN: 2250-1991.

Som, L. (2013), "Corporate governance of public sector enterprises in India”, ICRA Bulletin on Money and Finance, available at: www.icra.in/Files/MoneyFinance/Lalita\%20Som.pdf

Gakhar, D.V. and Phukon, A. (2018), "From welfare to wealth creation: a review of the literature on privatization of state-owned enterprises", Vol. 31, No. 2, pp. 265-286, available at: https://doi.org/ 10.1108/IJPSM-03-2017-0096

Wolf, C. and Pollitt, M.G. (2008), "Privatising national oil companies: assessing the impact on firm performance", Working paper series 02/2008, Judge Business School, Cambridge University, available at: http://papers.ssrn.com/sol3/papers.cfm?abstract_id=1088327

World Bank (2010), "Corporate governance of Central public sector enterprises in India”, Report published by the World Bank, available at: http://siteresources.worldbank.org/financial-sector/ Resources/India_CG_Public_Sector_Enterprises.pdf

Yadav, N.S., ; Srinivasa, K.G. and Reddy, B.E. (2019), “An IoT-based framework for health monitoring systems: a case study approach”, International Journal of Fog Computing, Vol. 2 No. 1, pp. 43-60, doi: 10.4018/IJFC.2019010102.

\section{Further reading}

Bruton, G.D., Peng, M.K., Ahlstrom, D., Stan, C. and Xu, K. (2015), "State-owned enterprises around the world as hybrid organizations", Academy of Management Perspectives, Vol. 29 No. 1, pp. 92-114, doi: 10.5465/amp.2013.0069.

OECD (2003), Privatizing State-Owned Enterprises: An Overview of Policies and Practices in OECD Countries, OECD Publishing, Paris.

Udeaja, E.A. (2006), "Privatisation and productive efficiency of firms in Nigeria", African Journal of Economic Policy, Vol. 13 No. 1, pp. 16-48. 
PRR

6,1

72

Table A1.

Regression model with return on net worth as dependent variable
Appendix

\begin{tabular}{|c|c|c|c|c|c|}
\hline \multirow[b]{2}{*}{ Independent variables } & \multicolumn{2}{|c|}{$\begin{array}{l}\text { Un-standardized } \\
\text { coefficients }\end{array}$} & \multirow{2}{*}{$\begin{array}{c}\text { Standardized } \\
\text { coefficients } \\
\text { Beta }\end{array}$} & \multirow[b]{2}{*}{$t$} & \multirow[b]{2}{*}{ Sig. } \\
\hline & $\mathrm{B}$ & Std. Error & & & \\
\hline (Constant) & 0.881 & 10.729 & & 0.082 & 0.937 \\
\hline Capital employed & 0.000 & 0.000 & 2.130 & 3.617 & 0.009 \\
\hline Raw material turnover ratio & 0.065 & 0.020 & 0.232 & 3.171 & 0.016 \\
\hline Interest coverage ratio & -0.004 & 0.001 & -0.312 & -3.098 & 0.017 \\
\hline Market capitalization & 0.000 & 0.000 & -0.111 & -0.659 & 0.531 \\
\hline Current ratio & -3.980 & 2.044 & -0.175 & -1.947 & 0.093 \\
\hline Dividend rate & 0.055 & 0.016 & 0.663 & 3.384 & 0.012 \\
\hline Earnings per share & 0.149 & 0.057 & 0.269 & 2.628 & 0.034 \\
\hline Gross working capital & 0.000 & 0.000 & -0.831 & -3.388 & 0.012 \\
\hline Expenditure on R\&D & -0.002 & 0.001 & -0.238 & -3.469 & 0.010 \\
\hline Sales efficiency & -0.319 & 0.102 & -0.923 & -3.127 & 0.017 \\
\hline Net income efficiency & 2.909 & 0.672 & 4.862 & 4.327 & 0.003 \\
\hline Disinvestment efficiency & -0.013 & 0.004 & -4.495 & -3.617 & 0.009 \\
\hline Profit or loss & 70.385 & 16.777 & 1.176 & 4.195 & 0.004 \\
\hline Industrial sector & -7.899 & 2.485 & -0.304 & -3.179 & 0.016 \\
\hline Performance contract & -110.273 & 19.206 & -2.147 & -5.742 & 0.001 \\
\hline Listing in stock exchange & -32.184 & 11.798 & -0.538 & -2.728 & 0.029 \\
\hline Corporate governance & 106.454 & 16.970 & 1.941 & 6.273 & 0.000 \\
\hline Explanation of the model & \multirow{4}{*}{$\begin{array}{l}0.987 \\
0.956\end{array}$} & & \multicolumn{3}{|c|}{ Significance of the model: } \\
\hline$R$ square & & & \multirow{3}{*}{$\begin{array}{l}\mathrm{F} \\
\text { Sig. }\end{array}$} & \multirow{2}{*}{\multicolumn{2}{|c|}{$\begin{array}{r}31.825 \\
0.000\end{array}$}} \\
\hline Adjusted R square $\left(R^{2}\right)$ & & & & & \\
\hline Durbin-Watson test $=1.633$ & & & & & \\
\hline
\end{tabular}




\begin{abstract}
About the authors
Shri Abhijit Phukon started his career by teaching business economics and international business environment. An Officer of the Indian Economic Service (IES), he has been currently serving as Director to Ministry of Corporate Affairs, Government of India (currently pursuing PhD from Guru Govind Singh Indraprastha University, Delhi). In the past 19 years of career, he has been closely associated with formulation and implementation of economic policies at a national level. His key sectoral exposure includes trade, commerce, finance, infrastructure, power and energy, public private partnership, capacity building, skill development, corporate affairs including corporate governance, corporate social responsibility, business responsibility reporting (BRR), business and human rights, companies act, competition act, etc. He has closely worked with many multi-lateral agencies including Asian Development Bank, World Bank, International Finance Corporation, World Trade Organization, KfW German Bank and DFID on a range of issues. His areas of interest include political economy reforms, development administration, global economic integration, environment sustainability, economic diplomacy and international relation. Abhijit Phukon is the corresponding author and can be contacted at: abhijitphukon@yahoo.co.in

Dr Divya Verma Gakhar is working as an Assistant Professor, University School of Management Studies, Guru Gobind Singh Indraprastha University, Delhi. Prior to joining this institution, she worked as a Lecturer in the Department of Management, Kurukshetra University, Kurukshetra. She has completed her doctoral research project on the subject "Web-based Corporate Reporting Practices in India" from Guru Jambheshwar University of Science and Technology, Hisar. She has a bright academic record and have won University scholarships during her graduation and post-graduation studies. She has also qualified DOEACC A Level computer course. Her areas of academic interest include accounting and finance, financial derivatives, behavioural finance, economics and ecommerce. She has authored and edited four books, namely, Micro and Macro Economics, Web-based Corporate Reporting Practices in India, Contemporary Issues in Corporate Finance and Emerging Issues in Indian Financial Markets. She has completed UGC-funded Major Research Project titled "Financial Derivatives Market in India: Present Status and Future Prospects".
\end{abstract}

For instructions on how to order reprints of this article, please visit our website: www.emeraldgrouppublishing.com/licensing/reprints.htm Or contact us for further details: permissions@emeraldinsight.com 